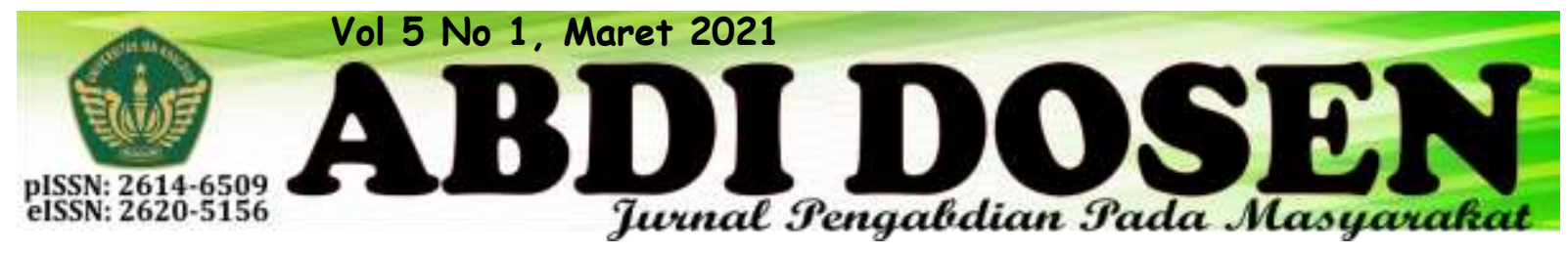

\title{
ANALISIS DESKRIPTIF PHBS DAN STATUS GIZI MASYARAKAT UPAYA PENINGKATAN STATUS KESEHATAN MELALUI PENDEKATAN KOLABORATIF BERBAGAI PEMANGKU KEPENTINGAN
}

\author{
Humaira Anggie Nauli \\ humaira@uika-bogor.ac.id \\ Fakultas Ilmu Kesehatan, Universitas Ibn Khaldun
}

\begin{abstract}
ABSTRAK
Meskipun secara nasional kualitas kesehatan masyarakat telah meningkat, akan tetapi disparitas status kesehatan antar tingkat sosial ekonomi, antar kawasan, dan antar perkotaanperdesaan masih cukup tinggi. Sebagai bentuk realisasi tri darma perguruan tinggi, Fakultas Ilmu Kesehatan Universitas Ibn Khaldun Bogor kepada masyarakat sekitar, mahasiswa dengan bimbingan dari dosen terkait melakukan Praktek Belajar Lapangan (PBL) kepada masyarakat Kota Bogor, khususnya di Kelurahan Cipaku, Kecamatan Bogor Selatan. Perencanaan program dilakukan dengan koordinasi Puskesmas Bogor Selatan dan Posyandu yang berada di bawah binaan Puskesmas tersebut. Pengabdian masyarakat ini terdiri dari 2 kegiatan utama yakni 1) Inisiasi revitalisasi dan pembangunan sarana kebersihan berupa jamban dan 2) Pendataan status gizi balita sebagai data dasar penentuan status kesehatan masyarakat. Hasil dari rencana tersebut mengemukakan bahwa Sebagian besar rumah memang sudah memiliki jamban (89\%), namun angka ini akan sia-sia jika masih terdapat risiko penyebaran kuman penyakit dari $11 \%$ rumah yang tidak memiliki jamban. Walau angkanya kecil (2\%), tidak adanya jamban membuat masyarakat masih melakukan kegiatan buang air kecil dan buang air besar secara sembarangan. Selaiun itu, sebagian besar Balita di Kelurahan Cipaku yang memiliki status BB/U baik (61\%). Namun, status BB/U sebanyak $34 \%$ Balita masih dibawah di bawah garis normal dan sudah ada $5 \%$ balita dengan $\mathrm{BB} / \mathrm{U}$ di atas garis normal. Jika dibiarkan, Balita akan memiliki risiko untuk memiliki berbagai masalah gizi dan kesehatan saat masa Balita atau di periode umur berikutnya. Begitu pula dengan status $\mathrm{TB} / \mathrm{U}$, masih terdapat lebih dari sepertiga (33\%) Balita yang memiliki status TB/U di bawah garis normal. Jika terabaikan dan terjadi menahun, stunting akan menjadi masalah gizi baru di Kelurahan Cipaku.
\end{abstract}

Kata Kunci : PHBS, Sampah, Simple Random Sampling, Masyarakat Leuwisadeng.

\section{PENDAHULUAN}

Pembangunan bidang kesehatan merupakan upaya untuk memenuhi salah satu hak dasar rakyat, yaitu hak untuk memperoleh pelayanan kesehatan sesuai dengan amanat negara kepada rakyatnya yang tercantum di Undang-Undang Dasar
1945. Pembangunan kesehatan harus dipandang sebagai suatu investasi untuk peningkatan kualitas sumber daya manusia, yang antara lain diukur dengan Indeks Pembangunan Manusia (IPM). Salah satu bagian penting IPM adalah 
aspek kesehatan, selain pendidikan dan pendapatan. Kesehatan juga merupakan investasi untuk mendukung pembangunan ekonomi serta memiliki peran penting dalam upaya penanggulangan kemiskinan.

Dalam pelaksanaan pembangunan kesehatan dibutuhkan perubahan cara pandang (mindset) dari paradigma sakit ke paradigma sehat, sejalan dengan visi Indonesia Sehat 2045. Konsekuensi jangka menengah yang terjadi diantaranya dalam bidang ekonomi yaitu meningkatnya health expenditure dan meningkatkan peluang untuk mengobati anak-anak yang sakit. Stunting adalah salah satu masalah kesehatan pada anak dan kini menjadi prioritas. Gerakan pembangunan tersebut dapat dilihat dari dinamika programprogram pembangunan manusia.

Meskipun secara nasional kualitas kesehatan masyarakat telah meningkat, akan tetapi disparitas status kesehatan antar tingkat sosial ekonomi, antar kawasan, dan antar perkotaan-perdesaan masih cukup tinggi. Angka kematian bayi dan angka kematian balita pada golongan termiskin hampir empat kali lebih tinggi dari golongan terkaya. Selain itu, angka kematian bayi dan angka kematian ibu melahirkan lebih tinggi di daerah perdesaan, di kawasan timur Indonesia, serta pada penduduk dengan tingkat pendidikan rendah. Persentase anak balita yang berstatus gizi kurang dan buruk di daerah perdesaan lebih tinggi dibandingkan daerah perkotaan. Pertolongan persalinan oleh tenaga kesehatan terlatih dan cakupan imunisasi pada golongan miskin lebih rendah dibanding dengan golongan kaya.

Perilaku hidup bersih dan sehat masyarakat merupakan salah satu faktor penting untuk mendukung peningkatan status kesehatan penduduk. Perilaku masyarakat yang tidak sehat dapat dilihat dari kebiasaan merokok, rendahnya pemberian air susu ibu (ASI) eksklusif, tingginya prevalensi gizi kurang dan gizi lebih pada anak balita, serta kecenderungan meningkatnya jumlah penderita HIV/AIDS, penderita penyalahgunaan narkotika, psikotropika, zat adiktif (NAPZA) dan kematian akibat kecelakaan.

Program peningkatan derajat kesehatan masyarakat dengan system kolaborasi ditujukan untuk memberdayakan individu, keluarga, dan masyarakat agar mampu menumbuhkan perilaku hidup sehat dan mengembangkan upaya kesehatan bersumber masyarakat. Program tersebut harus dilakukan secara massif di berbagai daerah dengan bermacam latar belakang sosial ekonomi.

Sebagai bentuk realisasi tri darma perguruan tinggi, Fakultas Ilmu Kesehatan Universitas Ibn Khaldun Bogor kepada masyarakat sekitar, mahasiswa dengan bimbingan dari dosen terkait melakukan Praktek Belajar Lapangan (PBL) kepada masyarakat Kota Bogor, khususnya di Kelurahan Cipaku, Kecamatan Bogor Selatan. 


\section{METODE}

\section{Waktu dan Lokasi}

Kegiatan ini merupakan bentuk kegiatan pengabdian kepada masyarakat dengan sasaran 344 Keluarga yang berada di Dusun Cipaku, Kecamatan Bogor Selatan, Kota Bogor. Rangkaian kegiatan ini dilakukan selama 2 bulan mulai dari bulan September 2019 sampai dengan November 2019.

\section{Analisis Masalah dan Strategi Saat ini dari Pemangku Kepentingan}

Berdasarkan asesmen awal dari diskusi dengan pemangku kepentingan dan peninjauan langsung berikut beberapa masalah dan tantangan yang dihadapi oleh Kelurahan Cipaku serta strategi pemangku kepentingan dalam mengatasinya.

a. Kematian Ibu Melahirkan

Saat ini di Kelurahan Cipaku, angka kematian ibu ketika melahirkan sudah mengalami penurunan. Namun, jumlahnya tetap masih jauh dari target yang diharapkan. Hal ini disebabkan oleh kualitas pelayanan kesehatan ibu yang belum memadai, kondisi ibu hamil yang tidak sehat, dan faktor-faktor lainnya. Penyebab utama kematian ibu adalah hipertensi kehamilan dan perdarahan postpartum. Selain itu, kondisi yang sering kali menyebabkan kematian ibu adalah penanganan komplikasi, anemia, diabetes, malaria, dan umur yang terlalu muda. Untuk menanggulangi hal ini, pemnagku kepentingan tengah mengintensifkan program kesehatan dari puskesmas, diiringi pula dengan peningkatan kualitas pelayanannya. Pemerintah juga sedang menciptakan pola keanekaragaman makanan untuk gizi ibu hamil. Program KB yang dicanangkan juga digunakan untuk menurunkan angka kematian ibu.

\section{b. Kematian Bayi dan Balita}

Serupa dengan angka kematian ibu akibat melahirkan, saat ini Kelurahan Cipaku masih jauh dari target yang seharusnya dicapai. Penyebab kematian utama pada bayi dan balita Berat Bayi Lahir Rendah (BBLR). Sedangkan untuk balita, penyebab kematian utama yang dialami adalah pneumonia dan diare. Faktor lingkungan serta kondisi ibu sebelum dan selama kehamilan menjadi faktor yang paling mempengaruhi kejadian ini. Maka dari itu, untuk menangani tantangan ini pemangku kepentingan menciptakan langkah-langkah persiapan untuk calon ibu, agar mereka benar-benar siap menghadapi kehamilan dan persalinan.

\section{c. Masalah Gizi Ganda}

Masyarakat Kelurahan Cipaku tidak hanya masih mengalami masalah kekurangan gizi namun juga sudah banyak yang mengalami masalah kelebihan gizi. Kondisi stunting sebagai masalah kekurangan gizi mikro menahun juga menjadi fokus tersendiri yang disebabkan oleh kemiskinan dan pola asuh yang tidak tepat, sehingga mengakibatkan kemampuan kognitif tidak berkembang secara maksimal, mudah sakit, maupun berdaya saing rendah. Untuk mengatasi masalah stunting, pemaangku kepentingan mengadakan program sosialisasi kepada masyarakat agar dididik untuk memahami pentingnya gizi bagi ibu dan anak. Pemerintah menetapkan fokus pada 1000 hari pertama kehidupan, terhitung sejak konsepsi hingga anak berusia 2 tahun.

d. Penyakit Menular

Masalah penyakit menular juga masih mendominasi masalah kesehatan di Kelurahan Cipaku. Prioritas utama saat ini adalah membasmi TBC, malaria, DBD dan 
influenza. Selain itu, Keluarahan Cipaku juga masih belum sepenuhnya mampu mengendalikan penyakit seperti kusta, filariasis, dan leptospirosis. Strategi pemangku kepentingan dalam memberantas masalah ini adalah dengan meningkatkan vaksin dan imunisasi, seperti polio, campak, difteri, pertusis, hepatitis B, dan tetanus. Strategi ini terbukti ampuh, karena pada tahun 2014 Kelurahan Cipaku sudah dinyatakan bebas polio. Selain itu, untuk menurunkan tingginya risiko penyakit menular, pemangku kepentingan juga mengembangkan Early Warning and Respons System (EWARS) atau Sistem Kewaspadaan Dini dan Respon (SKDR). Melalui sistem EWARS ini, diharapkan ada peningkatan dalam deteksi dini dan respons terhadap peningkatan tren kasus penyakit tertentu.

e. Meningkatnya Penyakit Tidak Menular

Dalam beberapa tahun terakhir masalah penyakit tidak menular telah menjadi beban utama masyarakat Keluarahan Cipaku ketimbang penyakit menular. Penyakit tidak menular yang paling banyak menyerang adalah hipertensi, diabetes mellitus, kanker, dan penyakit paru obstruktif kronik (PPOK). Selain itu, jumlah kematian akibat rokok juga terus meningkat. Strategi pemangku kepentingan dalam menanggulangi masalah ini adalah dengan melaksanakan Pos Pembinaan Terpadu Pengendalian Penyakit Tidak Menular (Posbindu-PTM), sebagai upaya memonitor dan deteksi dini faktor risiko penyakit tidak menular di masyarakat. Deteksi dini sangat penting, karena sebagian besar masyarakat Indonesia tidak menyadari bahwa dirinya menderita penyakit tidak menular. Oleh sebab itu, pemerintah juga berencana untuk meningkatkan sosialisasi dan program jaminan kesehatan seperti BPJS.

f. Kesehatan Jiwa

Saat ini, tanpa banyak disadari permasalahan kesehatan jiwa di Kelurahan Cipaku sudah besar dan menimbulkan beban kesehatan yang signifikan. Masalah gangguan jiwa berkaitan dengan masalah perilaku, dan sering kali berujung pada kondisi yang membahayakan diri seperti bunuh diri. Untuk menanggulangi hal ini, pemangku kepentingan memprioritaskan pengembangan Upaya Kesehatan Jiwa Berbasis Masyarakat (UKJBM) yang ujung tombaknya adalah puskesmas. Program ini bekerja sama dengan masyarakat, untuk mencegah meningkatnya gangguan jiwa.

\section{Perencanaan Program}

Perencanaan program dilakukan dengan koordinasi Puskesmas Bogor Selatan dan Posyandu yang berada di bawah binaan Puskesmas tersebut. Pengabdian masyarakat ini terdiri dari 2 kegiatan utama yakni 1) Inisiasi revitalisasi dan pembangunan sarana kebersihan berupa jamban dan 2) Pendataan status gizi balita sebagai data dasar penentuan status kesehatan masyarakat. Teknis perencanaan dan hasil yang diharapkan dapat dilihat di Tabel 1 berikut: 
Tabel 1. Teknis perencanaan program dan hasil yang diharapkan

\begin{tabular}{|c|c|c|c|c|}
\hline No. & Kegiatan & Teknis Pelaksanan & $\begin{array}{l}\text { Hasil Yang } \\
\text { Diharapkan }\end{array}$ & $\begin{array}{c}\text { Pihak } \\
\text { Kolaborasi }\end{array}$ \\
\hline 1 & $\begin{array}{l}\text { Inisiasi } \\
\text { revitalisasi } \\
\text { dan } \\
\text { pembangunan } \\
\text { sarana PHBS }\end{array}$ & $\begin{array}{l}\text { 1. Pendataan kuantitas dan } \\
\text { kualitas sarana kebersihan } \\
\text { yang ada di Kelurahan } \\
\text { Cipaku } \\
\text { 2. Musyawarah penentuan } \\
\text { prioritas perbaikan dan } \\
\text { pembangunan sarana } \\
\text { kebersihan } \\
\text { 3. Crowdfunding untuk biaya } \\
\text { perbaikan dan pembangunan } \\
\text { sarana kebersihan }\end{array}$ & 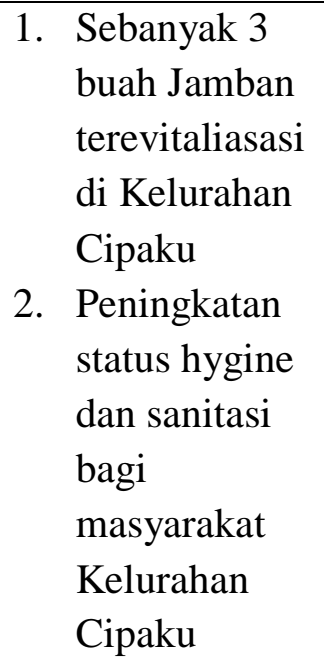 & $\begin{array}{l}\text { Stakeholder } \\
\text { Kelurahan } \\
\text { Cipaku }\end{array}$ \\
\hline 2 & $\begin{array}{l}\text { Pendataan } \\
\text { status gizi } \\
\text { Balita }\end{array}$ & $\begin{array}{l}\text { 1. Konsolidasi dengan } \\
\text { Puskesmas Kecamatan Bogor } \\
\text { Selatan dan Posyandu di } \\
\text { Kelurahan Cipaku } \\
\text { 2. Modifikasi jadwal Posyandu } \\
\text { dengan tambahan agenda } \\
\text { penilaian status gizi } \\
\text { 3. Pencatatan hasil penilaian } \\
\text { status gizi dan rekap seluruh } \\
\text { posyandu objek } \\
\text { 4. Presentasi dan advokasi ke } \\
\text { pihak stakeholder di } \\
\text { Puskesmas Kecamatan } \\
\text { Cipaku }\end{array}$ & $\begin{array}{l}\text { 1. Terdapat basis } \\
\text { data sebagai } \\
\text { patokan utama } \\
\text { pengambilan } \\
\text { kebijakan } \\
\text { kesehatan di } \\
\text { Kelurahan } \\
\text { Cipaku } \\
\text { 2. Terlaksananya } \\
\text { system } \\
\text { rujukan } \\
\text { kesehatan } \\
\text { yang baik } \\
\text { antara desa } \\
\text { dan Puskemas }\end{array}$ & $\begin{array}{l}\text { Puskesmas } \\
\text { Kecamatan } \\
\text { Bogor } \\
\text { Selatan dan } \\
\text { seluruh } \\
\text { Posyandu } \\
\text { di } \\
\text { Kelurahan } \\
\text { Cipaku }\end{array}$ \\
\hline
\end{tabular}

\section{Pelaksanaan Program}

a. Program Gizi meliputi :

1. Edukasi pemberian ASI eksklusif sangatlah penting namun terkadang masyarakat kurang mengikuti program tersebut, karena kesibukan ke kebun.

2. Edukasi konsumsi sayur dan buah setiap hari masyarakat setiap hari sudah mengkonsumsi sayur dan buah karena rata-rata masyarakat berkebun sayur dan buah atau menanam sendiri di pekarangan rumah. b. Program KIA meliputi:

1. Penimbangan bayi dan balita di bawa ke posyandu menurut masyarakat sangatlah baik, karena para ibu dapat mengetahui status kesehatan bayi dan balita setiap bulan, namun program tersebut masih kurang di sosialisasikan di Desa Buntuna.

2. Pertolongan persalinan oleh tenaga kesehatan baik dokter maupun bidan masyarakat sudah mulai menyadari akan hal itu namun masih tetap menggunakan dukun untuk merawat 
sehabis bersalin.

c. Program Kesehatan Lingkungan meliputi:

1. Edukasi penggunaan air bersih untuk kebutuhan sehari-hari masyarakat masih kesulitan mendapatkan air bersih karena belum ada program dari pemerintah setempat.

2. Edukasi untuk mencuci tangan yang benar dengan air bersih dan sabun, mencuci tangan sebelum makan dan sesudah buang air besar masih sangat kurang masyarakat bahkan masih sering lupa untuk mencuci tangan.

3. Penggunaan jamban sehat masyarakat masih banyak yang belum memiliki jamban karena masalah ekonomi mereka kebanyakan menggunakan wc umum atau buang air besar di sungai

4. Pemberantasan jentik nyamuk di Desa Buntuna masih kurang di programkan

\section{HASIL DAN PEMBAHASAN}

\section{Ketersediaan Jamban, Pembuangan} Ajhir dan Jenisnya

Jamban merupakan suatu ruangan yang mempunyai fasilitas pembuangan kotoran manusia yang terdiri atas tempat jongkok atau tempat duduk dengan leher angsa atau tanpa leher angsa yang dilengkapi dengan unit penampungan kotoran air untuk membersihkannya. Menurut Kemenkes (2014) sebuah jamban disebut sehat jika memenuhi syarat-syarat sebagai berikut:

1. Tidak mengotori permukaan tanah di sekeliling jamban tersebut.

2. Tidak mengotori air permukaan dan air tanah di sekitarnya.

3. Tidak dapat terjangkau oleh serangga terutama lalat, kecoa, dan binatang lain.

4. Tidak menimbulkan bau, mudah digunakan dan dipelihara. oleh pemerintah bahkan masyarakat membeli sendiri bubuk abate untuk di taruh di tempat penampungan air.

d. Program Gaya Hidup meliputi :

1. Edukasi untuk melakukan kegiatan olahraga sebelum aktivitas fisik setiap hari ketika pergi ke kebun masyarakat menggap itu sebagai kegiatan olah raganya karena dapat menggerakkan seluruh anggota tubuh dan mengeluarkan keringat ketika sedang bekerja.

2. Edukasi untuk tidak merokok di dalam rumah. Karena, bagi sebagian masyarakat adalah hal yang biasa bagi para kepala keluarga, namun bagi para ibu rumah tangga sangatlah berbahaya karena asap rokok dapat mengakibatkan berbagai penyakit dan tidak baik bagi kesehatan anak.

Data yang dapat dilihat di Gambar 1 menunjukkan bahwa masih terdapat masyarakat di Kelurahan Cipaku yang tidak menggunakan jamban sebagai sarana kebersihan pembuangan air kecil dan air besarnya. Target dari Kemeneterian Kesehatan (2008) dalam pedoman Sanitasi Total Berbasis Masyarakat diharapkan semua kepala keluarga sudah memiliki jamban belum tercapai. Sebagian besar rumah memang sudah memiliki jamban (89\%), namun angka ini akan sia-sia jika masih terdapat risiko penyebaran kuman penyakit dari $11 \%$ rumah yang tidak memiliki jamban. Walau angkanya kecil (2\%), tidak adanya jamban membuat masyarakat masih melakukan kegiatan buang air kecil dan buang air besar secara sembarangan. 


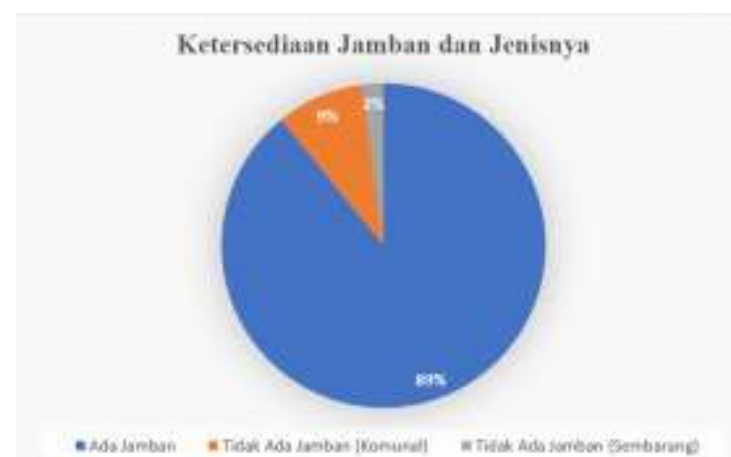

Gambar 1. Ketersedian jamban dan jenisnya di Kelurahan Cipaku

Perilaku buang air besar sembarangan (Open defecation) termasuk salah satu contoh perilaku yang tidak sehat. Open defecation merupakan suatu tindakan membuang kotoran atau tinja di ladang, hutan, semak-semak, sungai, pantai atau area terbuka lainnya dan jika dibiarkan menyebar mengontaminasi lingkungan, tanah, udara dan air (Notoatmodjo 2001). Perilaku ini dapat mengakibatkan berbagai macam dampak negatif. Tinja manusia ialah buangan padat dan kotor dan bau juga menjadi media penularan penyakit bagi masyarakat. Kotoran manusia mengandung organisme pathogen yang dibawa air, makanan, lalat menjadi penyakit seperti salmonella, vibriokolera, disentri, diare dan lainnya. Kotoran mengandung agen penyebab infeksi masuk saluran pencernaan. Menurut Supariasa (2008) penyakit yang ditimbulkan oleh kotoran manusia dapat digolongkan menjadi:

a. Penyakit enterik atau saluran pencernaan dan kontaminasi zat racun.

b. Penyakit infeksi oleh virus seperti Hepatitis infektiosa

c. Infeksi cacing seperti schitosomiasis, ascariasis, ankilostomiasis.

Tempat pembuangan akhir jamban yang terdapat di Keluarahan Cipaku dapat digolongkan menjadi dua (2) jenis yakni menggunakan Septic Tank dan Cubluk.
Sebagian besar jamban di Kelurahan Cipaku sudah menggunakan Septic Tank. Septic tank merupakan suatu kolam atau bak bersekat-sekat sehingga terbagi-bagi dalam beberapa ruang, biasanya terdapat di bawah tanah. Septic tank adalah tempat pembuangan yang dibuat tangki ini dibuat dengan bahan yang kedap air sehingga air dalam tangki septik tidak dapat meresap ke tanah (Suparmin 2001). Septic tank berguna untuk pembuangan kotoran, tinja, dan sebagainya, yang tidak boleh disalurkan ke saluran pembuangan umum karena kekotorannya, dimaksudkan untuk menjaga kesehatan dan kebersihan lingkungan. Septic tank akan menjadikan air pembuangan dan bahan padat yang ikut diberi kesempatan membusuk dan musnah secara alamiah. Air yang keluar karena berlebih dibuang ke sumur septik yang dapat meneruskannya ke air tanah tanpa mengganggu kebersihan air tanah. Jika tidak diguyur dengan obat pembasmi renik, untuk jangka waktu lama, tangki septik tidak perlu dikuras. Cubluk merupakan unit pengolahan awal dari limbag rumah tangga yang paling sederhana. Cubluk terdiri atas lubang yang digali secara manual dengan dilengkapi dinding rembes air yang dibuat dari pasangan batu bata berongga, sistim ini berfungsi sebagai tempat pengendapan tinja dan juga media peresapan dari cairan yang masuk

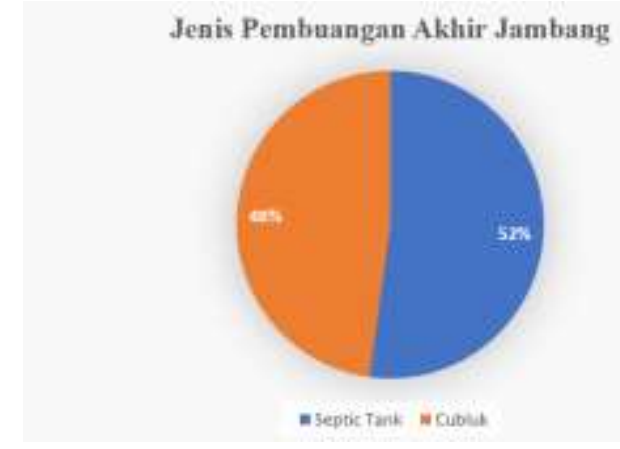

Gambar 2. Ketersedian jamban dan jenisnya di Kelurahan Cipaku 


\section{Status Gizi Balita menurut $B B / U$ dan} $\mathrm{TB} / \mathrm{U}$

Indikator status gizi berdasar indeks Berat Badan menurut Umur (BB/U) memberikan indikasi masalah gizi secara umum. Menurut Saaka (2014) indikator ini tidak memberikan masalah gizi yang sifatnya kronis ataupun akut karena berat badan berkorelasi positif dengan umur dan tinggi badan. Indikator BB/U yang rendah dapat disebabkan karena pendek (masalah gizi kronis) atau sedang menderita diare atau penyakit infeksi lain (masalah gizi akut..

Penentuaan gangguan gizi kurang menurut Kementerian Kesehatan (2020) dapat dilakukan dengan berbagai indicator antropometri dengan makna yang berbeda dalam memandang kejadian kurang gizi yang terjadi:

a. BB/U: menggambarkan ada tidaknya gangguan gizi umum

b. TB/U: menggambarkan ada tidaknya gangguan gizi kronis

c. Indek BB/TB: menggambarkan ada tidaknya gangguan gizi akut (Kemenkes RI dan WHO).

Anak dengan status gizi kurang pada tingkat ringan dan atau sedang masih seperti anak-anak lain, beraktivitas, bermain dan sebagainya, tetapi bila diamati dengan seksama badannya mulai kurus dan staminanya mulai menurun. Pada fase lanjut (gizi buruk) menurut Hidayati (2010) akan rentan terhadap infeksi, terjadi pengurusan otot, pembengkakan hati, dan berbagai gangguan yang lain seperti peradangan kulit, infeksi, kelainan organ dan fungsinya (akibat atrophy / pengecilan organ tersebut) (Khomsan et al, 2013).

Sebagian besar Balita di Kelurahan Cipaku yang memiliki status BB/U baik (61\%). Data yang ada di Gambar 2 juga didapat keterangan bahwa lebih dari sepertiga Balita di Kelurahan Cipaku memiliki masalah gizi yakni sebanyak $34 \%$ untuk BB/U di bawah garis normal dan sudah ada $5 \%$ balita dengan $\mathrm{BB} / \mathrm{U}$ di atas garis normal. Jika dibiarkan, menurut Khomsan A. (2003) Balita tersebut akan memiliki risiko untuk memiliki berbagai masalah gizi dan kesehatan saat masa Balita atau di periode umur berikutnya.

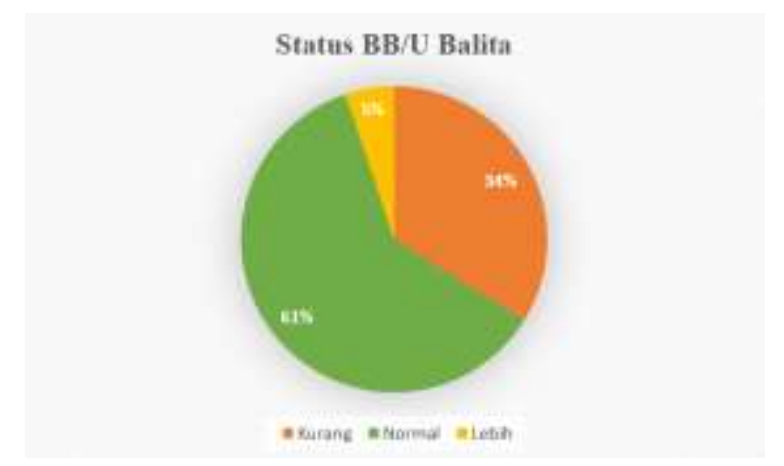

Gambar 3. Status BB/U Balita Kelurahan Cipaku

Begitu pula dengan status TB/U Balita di Kelurahan Cipaku, masih terdapat lebih dari sepertiga (33\%) Balita yang memiliki status $\mathrm{TB} / \mathrm{U}$ di bawah garis normal. Sisanya $65 \%$ memiliki status TB/U normal dan lebih (2\%). Stunting merupakan klasifikasi dari indikator status gizi TB/U. Menurut Achadi EL. (2014) anak yang dikatakan stunting adalah ia yang memiliki tinggi badan tidak sesuai dengan umurnya, biasanya ia akan lebih pendek daripada anak seusianya. Stunting merupakan akibat dari kurangnya asupan gizi dalam jangka waktu yang panjang, sehingga anak tidak bisa mengejar ketertinggalan pertumbuhan tinggi badannya. 


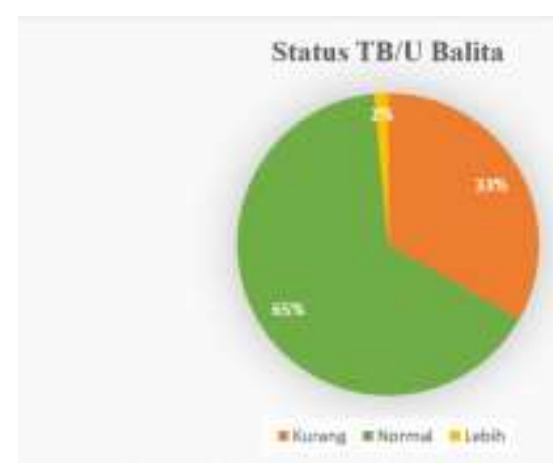

Gambar 4. Status BB/U Balita Kelurahan Cipaku

\section{KESIMPULAN}

Perencanaan program dilakukan dengan koordinasi Puskesmas Bogor Selatan dan Posyandu yang berada di bawah binaan Puskesmas tersebut. Pengabdian masyarakat ini terdiri dari 2 kegiatan utama yakni 1) Inisiasi revitalisasi dan pembangunan sarana kebersihan berupa jamban dan 2) Pendataan status gizi balita sebagai data dasar penentuan status kesehatan masyarakat. Hasil dari rencana tersebut mengemukakan bahwa Sebagian besar rumah memang sudah memiliki jamban (89\%), namun angka ini akan siasia jika masih terdapat risiko penyebaran kuman penyakit dari $11 \%$ rumah yang tidak memiliki jamban. Walau angkanya kecil (2\%), tidak adanya jamban membuat masyarakat masih melakukan kegiatan

\section{DAFTAR PUSTAKA}

Achadi EL. 2014. Periode kritis 1000 hari pertama kehidupan dan dampak jangka panjang terhadap kesehatan dan fungsinya. Fakultas Kesehatan Masyarakat, Universitas Indonesia. Cipta.

Hidayati. 2010. Pengetahuan dan sikap gizi kader dan ibu balita di posyandu dan pengaruhnya terhadap status gizi balita di Desa Babakan, Bogor Barat. [Skripsi]. Bogor (ID): Departemen Gizi Masyarakat, Fakultas Ekologi buang air kecil dan buang air besar secara sembarangan. Selaiun itu, sebagian besar Balita di Kelurahan Cipaku yang memiliki status BB/U baik (61\%). Namun, status BB/U sebanyak 34\% Balita masih dibawah di bawah garis normal dan sudah ada $5 \%$ balita dengan $\mathrm{BB} / \mathrm{U}$ di atas garis normal. Jika dibiarkan, Balita akan memiliki risiko untuk memiliki berbagai masalah gizi dan kesehatan saat masa Balita atau di periode umur berikutnya. Begitu pula dengan status $\mathrm{TB} / \mathrm{U}$, masih terdapat lebih dari sepertiga $(33 \%)$ Balita yang memiliki status TB/U di bawah garis normal. Jika terabaikan dan terjadi menahun, stunting akan menjadi masalah gizi baru di Kelurahan Cipaku.

Manusia, Institut Pertanian Bogor.

Kementerian Kesehatan. 2008. Keputusan Menteri Kesehatan Republik Indonesia no 852/MENKES/SK/IX/2008 tentang Strategi Nasional Sanitasi Total Berbasis Masyarakat. Kementerian Kesehatan. Jakarta.

Kementerian Kesehatan. 2020. Standar antropometri penilaian status gizi anak. Jakarta (ID): Badan Penelitian 
dan Pengembangan Kesehatan

Kementerian Kesehatan RI.

Khomsan A, Anwar F, Hernawati N, Suhanda NS, Warsito O, Herawati T. 2013. Growth, Cognitive Development and Psychosocial Stimulation of Preschool Children in Poor Farmer and Non-Farmer Households. Mal J Nutr. 19(3), 325 337.

Khomsan A. 2003. Pangan dan Gizi untuk Kesehatan. Jakarta (ID): PT. Rajagrafindo Persada.

Notoatmodjo S. 2003. Pendidikan dan Perilaku Kesehatan. Jakarta. Rineka
Saaka M. 2014. Relationship between mother's nutritional knowledge in childcare practices and the growth of children living in improverished rural communities. Health Popul Nutr. 32(2): 237-248.

Supariasa IDN, Bakri B, Hajar I. 2002. Penilaian Status Hidup Bersih dan sehat. Jakarta (ID): EGC.

Suparmin. 2001. Pembuangan tinja dan limbah cair: suatu pengantar. Jakarta: Jakarta. Penerbit Buku Kedokteran EGC 